\title{
OLHO-GORDO E FURA-OLHOS NA SOCIEDADE DO ESPETÁCULO: REFLEXÕES PSICOPOLÍTICAS SOBRE A INVEJA
}

\author{
Samara Megume Rodrigues* \\ Angela Maria Pires Caniato**
}

\begin{abstract}
Resumo: Opresente artigo discute o sentimento de inveja na sociedade contemporânea. Trata-se de uma pesquisa qualitativa baseada na Psicanálise e na Teoria Crítica. A inveja é um sentimento de natureza sadomasoquista, sendo sempre um ataque à possibilidade de amparo. Ela é um movimento narcísico fundamentado no mecanismo psíquico de idealização. O objetivo deste estudo é analisar tal sentimento na sociedade contemporânea, em que a imagem visual e a espetacularização da vida tornaram-se mediadores dos vínculos entre os sujeitos. A inveja mostrou-se não apenas como um afeto intensamente estimulado, mas também como um suporte subjetivo dos valores e condutas necessários à manutenção das atuais condições sociais de existência pautadas pela lógica da mercadoria.
\end{abstract}

Palavras-chave: inveja, idealização, mercadoria, indústria cultural.

Abstract: The current article discusses the feeling of jealousy in the contemporary

* Psicóloga Clínica e mestranda no Programa de Pós-Graduação em Psicologia da Universidade Estadual de Maringá (PPI-UEM). Integrante do projeto de pesquisa-intervenção "Phenix", vinculado do departamento de Psicologia (DPI-UEM). E-mail: samara.megume@gmail.com

** Professora do Programa de Mestrado em Psicologia na Universidade Estadual de Maringá. Representante do Núcleo de Maringá da Associação Brasileira de Psicologia Social (ABRAPSO). Possui curso de graduação em Psicologia (Licenciatura e Formação de Psicólogos) pela Pontifícia Universidade Católica do Rio de Janeiro (1968), titulação em Psicologia Clínica e Social pelo Conselho Federal de Psicologia (CFP), Mestre em Psicologia Social pela Pontifícia Universidade Católica de São Paulo (1986), e Doutora em Psicologia pela Universidade de São Paulo (1995). E-mail: ampicani@onda. com.br. 
$|250|$

Olho-gordo e fura-olhos na Sociedade do Espetáculo...

society. It is a qualitative research based on the Psychoanalysis and the Critical Theory. Envy is a feeling of sadomasochist nature, always being an attack to the support possibility. It is a narcissistic movement grounded on the psychic mechanism of idealization. The goal of this study is to analyze such feeling in the contemporary society, in which the visual images and the over featured of the life have become mediators of the links between the individuals. Envy shows itself not just with an intensely stimulated affection, but also as a subjective support of the necessary values and conducts to the maintenance of the actual social conditions of the existence guided by logic of the goods.

Keywords: envy, idealization, goods, cultural industry.

\section{Introdução}

O presente artigo discute o sentimento de inveja na sociedade contemporânea. Constitui-se de uma pesquisa qualitativa de cunho bibliográfico, desenvolvida dentro do plano epistemológico da Psicanálise, principalmente em seus pontos de cruzamento e intersecção com a Teoria Crítica da sociedade desenvolvida por Adorno e Horkheimer.

A origem etimológica da palavra inveja, do latim invidia, advém do verbo invideo, que significa olhar atravessado, olhar de soslaio. Significa também um sentimento de pena e raiva; sentimento de desgosto pela prosperidade ou alegria de outrem; desejo de possuir aquilo que os outros possuem; emulação e cobiça (CUNHA, 1991). A inveja advém de uma comparação não suportada entre o eu e o outro; é o impulso que leva a destruir o que o outro possui e o vínculo com ele.

As transformações históricas, sociais, econômicas e tecnológicas ocorridas principalmente nestas duas últimas décadas produziram alterações significativas na constituição da subjetividade humana. As inovações tecnológicas e os novos recursos da mídia passaram a cumprir um papel crucial na vida dos sujeitos, alterando suas formas de agir e pensar. Os meios de comunicação de massa como principais promotores e divulgadores de bens simbólicos passaram a ditar os ideais e a formar as identidades dos sujeitos. Com isso presenciamos um contexto em que ser alguém visível para as outras pessoas 
e exibir publicamente sua "personalidade" são formas de conferir importância à própria existência. Os meios de comunicação de massa, ao propagarem a lei de mercado, passam a institucionalizar a inveja nas relações sociais, pois a mercadoria passa a conferir prestígio social a quem a consome, configurando-se uma sociedade hierarquizada e dominada fundamentalmente pelas aparências, em que os múltiplos e complexos sentidos do ser humano estão subordinados ao poder do capital.

Em sua origem essa palavra já apresenta o verbo "olhar". No senso-comum também identificamos expressões que adjetivam o invejoso por meio desse verbo, como, por exemplo: pessoa que lança um "mau-olhado", que tem "olho-gordo", que vai "furar os olhos", que possui o olhar de "seca-pimenta", etc. A relação invejaolhar indica que esse sentimento provém de relacionamentos em que a imagem visual possui papel fundamental. Assim, em uma sociedade do espetáculo ${ }^{1}$ a inveja está sendo utilizada para dar suporte subjetivo à adesão dos sujeitos aos ditames da sociedade contemporânea, principalmente ao consumismo e à competição, tão necessários à manutenção das atuais condições sociais de existência.

Com o propósito de levantar reflexões sobre a dinâmica contemporânea da inveja seguimos uma abordagem histórica de nosso objeto de estudo. Inicialmente apresentamos e problematizamos seu conceito com base em duas formas de significação do sentir: as expressões culturais (mitologia, religião e cultura popular) e o estudo da subjetividade proposto pela Psicanálise. Posteriormente discutimos e refletimos sobre a dinâmica da inveja na contemporaneidade, apresentando os elementos da sociedade por meio de categorias como razão instrumental, indústria cultural/espetáculo. O exame crítico da contradição desses dois momentos nos possibilitou entender algumas estratégias de adesão dos sujeitos às mais diversas formas de violência social.

${ }^{1}$ Terminologia cunhada pelo autor Guy Debord (1997). 
$|252|$

Olho-gordo e fura-olhos na Sociedade do Espetáculo...

A inveja é um sentimento que possui uma grande e rica expressão nas esferas de construção simbólica dos homens, o que representa sua intensa complexidade, e algo parece ser comum a todas essas expressões: a inveja, que é destrutiva tanto para o invejoso quanto para o invejado. O vínculo que se estabelece em uma relação invejosa é de natureza sadomasoquista e é sempre um ataque a qualquer possibilidade de amparo e acolhimento. $\mathrm{O}$ invejoso deseja vorazmente tudo que o outro possui de bom, mas não pode gozar daquilo que o outro possui, pois não aceita esse bem para si. A inveja remonta a uma fase em que o sujeito ainda não conseguia distinguir claramente o eu do não eu. Ela é um movimento narcísico fundado na idealização.

A inveja estimulada na contemporaneidade impossibilita o sujeito de ser um, de construir sua singularidade, arquitetando um jogo em que ocorre o esvaziamento do pensar em face da espetacularização.

\section{Expressões da inveja na cultura}

\section{A inveja consome o invejoso como a ferrugem o ferro (Antístenes)}

O ser humano possui uma vivência significativa com o sentimento de inveja. Essa expressão psíquica se materializou na cultura por meio de uma infinidade de romances da literatura, da religião, das artes visuais, da música e da cultura popular. Isto atesta a riqueza das expressões de seus elementos constitutivos e as mais variadas formas que o homem buscou para entender e lidar com esse sentimento.

A inveja está presente na mitologia greco-romana já na história que narra a criação do mundo e do homem: o mito de Prometeu e Pandora. A inveja foi um sentimento suprimido do processo de criação. O deus Prometeu não a utilizou para fazer o homem, então a guardou em uma caixa, que foi mantida escondida; mas sua esposa, Pandora, abriu-a, deixando escapar 
muitos males, entre eles a inveja - que desde então passou a atormentar "o espírito" dos homens (BULFINCH, 2001).

Outra alegoria que representa a inveja na mitologia grecoromana é a do Cupido e da Psique. Esta, por sua beleza e pelo seu casamento com Cupido, foi invejada tanto por Afrodite (sua sogra) quanto por suas irmãs (BULFINCH, 2001). Interessantemente, na mitologia muitas históricas revelam a inveja atrelada à rivalidade/ competição entre irmãos.

O escritor latino Ovídio (2003), ao interpretar poeticamente os mitos gregos, narra uma passagem em que a deusa Palas Atenas vai até a morada da Inveja e lhe pede que infecte com seu veneno a Aglausos, uma jovem que era alvo da vingança de Palas. O escritor descreve a inveja da seguinte maneira:

Foi à casa da Inveja, uma negra moradia/ Manchada de sangue, uma casa escondida/ Num vale profundo, onde a luz do sol não alcançava,) Onde o vento não soprava, lugar enevoado, úmido, frio [...] As portas se abriram; e lá estava a Inveja/ Comendo a carne das serpentes/ Meio comidas espalhadas pelo chão, e veio andando até a porta[...] Pálida, esquálida, os olhos fundos/ Tingida de veneno, ela nunca ri,/ Exceto quando presencia sofrimento; nunca dorme,/ Sempre perturbada pela ansiedade; e se os homens/ Ganham, ela perde; consome e é consumida/ Pela autopunição.

(OVÍDIO, 2003, p. 48)

A inveja é analisada na mitologia como um sentimento arcaico, que é antigo na história da humanidade e simbolicamente arcaico na história do sujeito. Ela é recorrente entre pares, ou seja, representa um ataque aos vínculos fraternos. Na passagem de Ovídio (2003) fica evidente quanto a inveja é entendida como sendo destrutiva e relacionada ao sadismo, ao prazer na dor e sofrimento alheio. Esse prazer na dor leva a um círculo autodestrutivo, em que ocorre um culto ao sofrimento.

Esses elementos da inveja atravessaram a história da humanidade, estando também presentes na religião cristã, na arte e na cultura popular. Na Bíblia a inveja também está presente no 
início da criação do mundo e do homem e também é recorrente entre irmãos. Pela inveja o pecado entrou na terra. Satanás teria sido arrebatado pela inveja da proximidade do humano com Deus. Assim, ofereceu ao homem o fruto proibido (Bíblia. Genesis, $1 ; 2,24)$. O primeiro homicídio na terra é motivado pela inveja. Filhos de Adão e Eva, os irmãos Caim e Abel ilustram a íntima relação entre inveja e rivalidade fraterna. Na escritura cristã os elementos constitutivos da inveja são descritos sempre em relação com a desgraça e a destruição, ao ponto de ela ser definida como uma "podridão dos ossos" (Bíblia. Provérbios 17. v. 30)

São Tomás de Aquino (2005) apresenta a inveja como um pesar ante o bem do próximo, uma tristeza em relação ao bom que os outros possuem (Suma Teológica II- II q. 36, a. III). Desta forma cabe destacar a diferença entre inveja e admiração. Na primeira ocorre um ataque destrutivo ao bom que o outro possui, sendo que na última esse bom é reconhecido e se torna fonte da construção de ideais e amor. Na contemporaneidade ocorre a construção de um novo conceito: a inveja branca, que é sinônimo de admiração; porém esses sentimentos são contrários. O caráter destrutivo do sentimento de inveja é camuflado. $O$ ataque ao outro, uma característica desse sentimento, ocorre justamente pelo impedimento de aceitar o bom que o outro possui (KLEIN, 1957).

Por meio de uma pesquisa popular Ventura (1998) concluiu que a inveja é o mais conhecido dos pecados, porém é o menos assumido. De todos, ela é o único pecado que é "inconfessável" publicamente. Negada a si mesmo ou negada ao outro, na cultura popular ela aparece com um caráter mágico, aparentemente alheio e superior ao próprio sujeito. Por esse motivo existe uma infinidade de amuletos e artefatos materiais para a proteção contra esse sentimento: pimenta, olho-turco/olho-grego, figa, correntede-são-jorge, arruda, etc.

Ao longo dos anos foi atribuído à inveja um caráter mágico. Assim, é somente com artefatos também mágicos que ela pode ser combatida. Somente vestindo-se - trazendo para perto de si os 
amuletos, talismãs, ervas, etc. - com poderes superiores ao homem se está armado contra o mal que a inveja pode causar.

\section{Inveja e subjetividade: o ataque aos vínculos}

A inveja é a amargura que se sofre por causa da felicidade alheia

(Cícero)

Na Psicanálise a inveja surge em Freud (1905/1997) associada à descoberta da diferença anatômica entre os sexos, que ocorre na denominada fase fálica do desenvolvimento (Complexo de Édipo), em que os interesses da criança voltam-se para os genitais. A menina, ao se deparar com o fato de que o menino possui um pênis, sentir-se-ia lesada e, consequentemente, arrebatada pela inveja. Posteriormente Freud (1925/1997) irá afirmar que a primeira consequência da constatação da diferença anatômica entre os sexos é o sentimento de inferioridade. Freud (1937/1997) também aponta um problema clínico vinculado à inveja, qual seja: o invejoso não quer receber ajuda, pois não suporta que lhe deem nada de bom.

Na Psicanálise a inveja continuou sendo compreendida em relação com o sentimento de inferioridade e como elemento de oposição aos vínculos de amparo, as suas origens no psiquismo foram bastante contestadas. Melanie Klein (1957/1991) desenvolveu a tese de que a inveja teria origem na relação mãebebê, na primeira relação do ser humano. Nesse início da vida o bebê passa por oscilações entre ter e perder o contato com a mãe que representa sua fonte vital. Essa presença proporciona amparo e estímulos, e assim, a experiência de sua ausência é cruel, pois representa a privação dessas fontes. Desta forma, a transitoriedade do objeto e sua incapacidade de atender plena e continuamente aos desejos da criança dão origem ao ódio e ao ressentimento, que são característicos da inveja. Neste sentido, o bebê "sente que a gratificação de que foi privado foi guardada, para uso próprio, pelo seio que frustrou" (KLEIN, 1957/1991, p. 212). Essa intensa e 
| 256 |

Olho-gordo e fura-olhos na Sociedade do Espetáculo...

massiva idealização do seio/mãe dificulta a capacidade da criança de construir um verdadeiro objeto bom interno, de estabelecer a clara distinção entre o bom e o ruim. Nas palavras de Klein (1957/1991),

\begin{abstract}
A inveja é o sentimento raivoso de que outra pessoa possui e desfruta algo desejável - sendo o impulso o de tirar este algo ou estragá-lo. Além disso, a inveja pressupõe a relação do indivíduo com uma só pessoa e remonta à mais arcaica e exclusiva relação com a mãe (KLEIN, 1957/1991, p. 212)
\end{abstract}

Diferentemente do ciúme, que necessariamente pressupõe uma relação entre três ou mais pessoas, a inveja envolve unicamente o invejoso e o invejado/objeto de ataque. Ela é mais arcaica, pois remonta a uma fase em que o sujeito ainda não possuía capacidades egoicas para se diferenciar completamente do seu objeto de desejo. O ciúme representa o temor de perder o amor do objeto, as características boas que ele contém; já a inveja é um ataque a essas características e ao outro. Chuster e Trachtenber (2009, p. 5) citam a seguinte passagem de Pierre Charon, na epígrafe de seu livro:

Por sua natureza e seus efeitos, o ciúme se aproxima da inveja. Porém, entre ciúme e inveja permanecem algumas diferenças. Na inveja, sentimos que outros possuem um bem que desejamos para nós, enquanto no ciúme defendemos um bem que julgamos nosso e que não desejamos ver partilhado com outrem. (CHARON apud CHUSTER; TACHTENBER, 2009, p. 5)

Segundo Klein (1975), na inveja existe um desejo de posse que, de tão intenso, chega a tornar a vida crucial e amarga para os sujeitos que a experimentam, pois "sentem-se eles como se estivessem sendo forçados a submeter-se a roubo e a perseguição" (p. 51). Assim, o objeto invejado apresenta-se para o invejoso como sendo dele por direito, como algo que não era para ser do 
outro, mas seu, e então ele quer de volta o que não possui. Por esse motivo, o invejoso quer empobrecer o outro, retirar-lhe tudo.

Essa inveja vivenciada no início da vida é chamada de primária, e está presente, como marca do desenvolvimento, em todas as outras manifestações desse sentimento e em suas formas subsequentes, nas quais não mais se focaliza o seio, e sim, aspectos da relação dos pais e posteriormente a relação entre iguais.

Mezan (1997) ressalta que o objeto de inveja se faz pelo mecanismo psíquico da idealização. Ele é sobrevalorizado e supõe-se que detenha atributos extraordinários, por vezes mágicos. Nesse objeto idealizado existe algo que não resulta do sujeito que o detém, mas sempre, da fantasia de quem inveja; assim, "não existe inveja sem a projeção de algo idealizado" (p. 139).

$\mathrm{O}$ autor analisa que a projeção de algo no sujeito de intenso desejo é a perfeição narcísica, a completude. Assim, a inveja constitui-se de um movimento narcísico, pois o sujeito projeta partes da imagem idealizada de si mesmo, imagem que é perfeita, completa e grandiosa.

Diante do objeto idealizado o sujeito torna-se inferior, desprezível, uma vez que o objeto-suporte da inveja é tido como sendo independente das limitações impostas pela realidade, pela diferença entre os sexos, pela mortalidade do homem e pela finitude do corpo. O objeto-suporte da inveja apresenta-se com um poder superior ao sujeito que o inveja.

Mezan (1997) analisa que "o pênis invejado não é assim, o órgão do menino, mas um objeto idealizado que a menina projeta neste suporte e que tem a ver com o mundo fantasmático dela" (p. 148). Neste sentido, cabe destacar também a afirmação de Figueiredo e Cintra (2008) de que na Psicanálise "seio e pênis devem ser lidos como metáforas de todas as manifestações de algo desejável" (FIGUEIREDO; CINTRA, 2008, p. 76), pois representam toda a capacidade de oferecer alimento, vida, energia, prazer, amor, compreensão e todas as coisas tidas como boas. A inveja suscitada por esses elementos advém de um mecanismo psíquico em que o sujeito projeta seus anseios por perfeição narcísica, o que tem como consequência os sentimentos de raiva, ódio e sensação 
| 258 |

Olho-gordo e fura-olhos na Sociedade do Espetáculo...

de roubo, como evidenciado por Klein (1957), e de inferioridade, como analisado por Freud (1905/1997).

A inveja é uma manifestação da pulsão de morte, uma representação dos impulsos sádicos presentes no sujeito. (KLEIN, 1957/1991). Neste sentido, ela visa cumprir as exigências pulsionais de Tânatos, que são de reduzir ao máximo as tensões, levando-as ao nível zero de excitações: o repouso absoluto, a morte (FREUD, 1920/1997). A meta da pulsão de morte seria realizar uma função autodestrutiva, e para tanto ela possui mecanismos de desligamento dos objetos de investimento libidinal - daí sua descrição sempre sórdida ou macabra na mitologia grega, tal como apresentado por Ovídio (2003): a inveja mora numa negra moradia manchada de sangue, aonde a luz nem o vento chegam; ou seja, ela habita os próprios impulsos destrutivos dos sujeitos. Desta forma a inveja, com suas características específicas, cumpre de forma soturna e intensa as metas da pulsão de morte. Como observam Figueiredo e Cintra (2008, p. 74),

Toda inveja é endereçada a Eros: essa inveja é a força dirigida a desfazer o nó originário entre pulsões de vida e de morte, e seu objetivo é realizar um silencioso e sinistro trabalho de dissolução dos vínculos eróticos, pois o que precisa ser destruído pelo impulso invejoso é a própria dependência em relação às fontes de vida e de prazer e plenitude.

Ao atacar as qualidades boas do outro e o próprio vínculo com ele o sujeito invejoso fica em desamparo. Assim, a inveja acaba agindo como um autoataque. Atacar o que o outro possui de bom é atacar a própria dependência que se tem do vínculo com ele e, consequentemente, atacar o próprio desejo.

\section{Do mito à mistificação das massas: a inveja como espetáculo}

No atual contexto econômico, social e cultural a mercadoria tornou-se o novo senhor a ser idolatrado e obedecido, em que 
o sujeito só é valorizado - e até mesmo considerado em sua humanidade - quando exibe a posse dela; portanto a inveja tornase um afeto gradativamente utilizado para adesão dos sujeitos ao consumismo, visto que a mercadoria passou a conferir prestígio social a quem a consome. Assim se configura uma sociedade hierarquizada e dominada fundamentalmente pelas aparências, na qual os múltiplos e complexos sentidos do ser humano estão subordinados ao poder do capital.

A consolidação desse contexto articulou a decadência de alguns sistemas simbólicos de legitimação social e subjetiva, entre eles a religião, a cultura popular e a política. Atualmente o mercado se coloca como real substituto desses sistemas; porém, diferentemente deles, a mercadoria não possui as características necessárias para ser um referencial simbólico estruturante da subjetividade, visto que não fornece ao sujeito uma anterioridade fundadora a partir da qual se torne possível uma ordem temporal e subjetiva. Abdicar ao passado individual e social (presente nas tradições) se tornou algo necessário para a adaptação às novas normas de convívio cultural. Assim, os mitos, os valores e as normas que regulavam as relações entre os indivíduos são reestruturados em prol do mercado, o que leva a mudanças significativas na subjetividade humana e na forma como esta se vincula ao mundo e às relações. Neste sentido, as manifestações de inveja na contemporaneidade são qualitativamente expressas e explicadas de forma diferente das presentes na história cultural.

$\mathrm{O}$ mito surge em determinado momento histórico como a máxima explicação dos homens sobre o mundo, como uma tentativa de explicar as forças da natureza e seu império sobre a vida dos sujeitos. Horkheimer e Adorno (1985a) afirmam que desde sua origem o mito tinha a pretensão de "relatar, denominar, dizer a origem, mas também expor, fixar, explicar" (HORKHEIMER; ADORNO, 1985a, p. 23). Assim, ele consistia em uma forma arcaica de esclarecimento ${ }^{2}$.

${ }^{2}$ Esclarecimento é a tradução da palavra Aufklãrung, feita por Almeida no livro Dialética do Esclarecimento, de Horkheimer e Adorno (1985). O tradutor aponta 
$|260|$

Olho-gordo e fura-olhos na Sociedade do Espetáculo...

Horkheimer e Adorno (1985a), ao analisarem a trajetória da razão ocidental, afirmam que, desde as epopeias gregas até os sistemas racionalistas contemporâneos, a razão humana se condena à sua própria idolatria. Os autores analisam que o esclarecimento proposto pela ciência moderna, ao se aliar à dominação econômicosocial, converteu-se em uma nova mitologia. A ciência utilizou a razão para apagar todos os vestígios de contradições, reduzindo tudo à dimensão da lógica da identidade, e assim ela equalizou tudo à dimensão de mercadoria. Com o propósito de dominar a natureza e os homens, ela impôs a formalização, instrumentalização e coisificação da razão. Ou seja, "no trajeto para a ciência moderna, os homens renunciaram ao sentido e substituíram o conceito pela fórmula, a causa pela regra e pela probabilidade" (HORKHEIMER, ADORNO, 1985a, p. 21). Essa racionalidade técnica cumpre uma função econômica na sociedade - que passa a ser ela toda "administrada". Nas palavras de Horkheimer e Adorno (1985a, p. 24),

O mito converteu-se em esclarecimento, e a natureza em mera objetividade. O preço que os homens pagam pelo aumento de seu poder é a alienação sobre o que exercem o poder. O esclarecimento comporta-se com as coisas como o ditador se comporta com os homens. Este conhece-os na medida que pode manipulá-los. O homem de ciência conhece as coisas na medida em que pode fazê-las.

O pensamento foi reificado e transformou-se em apenas mais um instrumento. Neste sentido a ciência tornou-se enfeitiçada, um

que em alemão a palavra refere-se à expressão que designa a emancipação intelectual, a superação da ignorância, em que o mundo das trevas é vencido pela iluminação feita pela razão. Tal importância da razão tem seu ápice no século XVIII, conhecido como Época das Luzes ou Iluminismo. Em Adorno e Horkheimer o termo é usado para se referir ao "desencantamento do mundo", ou seja, é o processo em que o homem tenta se libertar do medo das potências místicas da natureza. 
fetiche, em que as explicações convertidas em dogmas passaram a subjulgar o próprio homem.

Em seu comércio, a mercadoria não aparece como produto de uma relação de produção humana, ou seja, o valor social nela se apaga e ela apresenta-se como se valesse por si mesma, como se tivesse vida autônoma. A mercadoria passa a ter um caráter místico religioso, como se estivesse enfeitiçada: o fetiche da mercadoria (MARX, 1867/1968). Ou seja, as leis da economia que a regem apresentam-se como naturais, independentes da história. Da mesma forma que a mercadoria (seu fetiche) encobre uma relação de classes em uma época histórica determinada, a ciência passou a ser utilizada como apenas um meio para se atingir a acumulação capitalista. Nesse sentido, ela também tornou-se uma mercadoria, sem história, que passou a encobrir as relações de exploração. Tal "feitiço da ciência" acabou por promover uma nova forma de mistificação dos sujeitos. Assim: "do mesmo modo que os mitos já levam a cabo o esclarecimento, assim também o esclarecimento fica cada vez mais enredado, a cada passo que dá, na mitologia" (HORKHEIMER, ADORNO, 1985a, p. 26)

A mitologia, por sua vez, diferentemente da ciência, não possuía utilidade prática. Ela servia de alegoria para as angústias dos homens. Por meio do antropomorfismo homem e natureza igualavam-se e distinguiam-se ao mesmo tempo. Com a razão instrumental utilizada pela ciência moderna essa distinção acaba. O homem passa a julgar-se onipotente e soberano na terra, não aceitando nenhuma limitação e assim deixa de ser servo dos mitos para servir voluntariamente ao capital.

A cultura e a arte tiveram seus potenciais emancipatórios neutralizados. A arte enquanto expressão cultural passa a ter um espaço cada vez mais reduzido, sendo progressivamente minada a possibilidade de ela se desenvolver. Segundo Horkheimer e Adorno "a obra de arte ainda tem em comum com a magia o fato de estabelecer um domínio próprio, fechado em si mesmo e arrebatado ao contexto da vida profana. Nesse domínio imperam leis particulares" (HORKHEIMER; ADORNO, 1985a, p. 32). A arte parece não poder mais desenvolver seu caráter de resistência, 
pois, seguindo a razão instrumental, não é mais regida por leis particulares, mas pelas leis do mercado.

A racionalidade técnica invade todas as esferas da vida humana, inclusive (e principalmente) a produção de bens culturais. A partir da reprodutibilidade mecânica desses bens, o que deveria promover a autonomia (singularidade/individuação) humana passa a gerar nivelamento, normatização e padronização. Toda a produção material e simbólica torna-se mercadoria. Desta maneira as esferas cultural e econômica passam a não ter mais distinções, configurando o que Horkheimer e Adorno (1985b) conceituam como indústria cultural.

A cultura deveria ser algo produzido para e pelos homens a fim de regular suas relações, em prol do amparo (FREUD, 1930/2011). Ela deveria possibilitar os elementos para que esses pudessem construir uma oposição crítica à realidade, necessária para a constituição da autonomia humana (ADORNO, 1986); porém a indústria cultural, ao propagar a lei do mercado e difundir de forma globalizada e niveladora a razão instrumental, promove a internalização na subjetividade da lei do mercado, que passa a se impor de forma totalitária e implícita a todos os aspectos da vida do sujeito.

Debord (1997) analisa que a sociedade passou a apresentarse "como uma imensa acumulação de espetáculos. Tudo o que era vivido diretamente tornou-se uma representação" (DEBORD, 1997, p. 13). Isto significa que com o desenvolvimento econômico e social ocorre uma transição cultural, em que o mais importante não é mais o acúmulo de mercadorias e de saberes, como o era na sociedade industrial, mas, fundamentalmente, a aparência da posse desses bens.

A indústria cultural impõe a primazia do poder econômico na determinação da vida humana e utiliza a primazia da imagem como veículo e instrumento dessa determinação. $\mathrm{Na}$ atual fase do desenvolvimento capitalista, a mercadoria descarta completamente seu valor de uso e passa a ser, ela toda, uma imagem abstrata: valor de troca. Com isso todas as experiências fundamentais da existência humana passam a ser realizadas sob a égide e monopólio 
de imagens visuais. O objeto da mercadoria torna-se tão somente seu poder simbólico, construído pela tecnologia de manipulação audiovisual (meios de comunicação de massa). Assim, como assinala Debord (1997), "espetáculo é o capital em tal grau de acumulação que se torna imagem" (DEBORD, 1997, p. 25)

A sociedade como espetáculo não se resume ao conjunto de imagens transmitidas pelos meios de comunicação, mas inclui algo que se interpõe nas relações sociais, as quais passam a existir somente pelas imagens visuais. Esse algo é a própria lógica da mercadoria. Nesse contexto, ser alguém visível para as outras pessoas, exibir publicamente sua "personalidade", é conferir importância à própria existência. A vida torna-se uma vitrine onde identidades-mercadorias podem expor o que possuem de bom ou de ruim. Com isso os meios de comunicação de massa, que são um campo de visibilidade, passam a possuir um papel central na luta pelo reconhecimento. Esse fenômeno pode ser conferido na crescente importância que as redes sociais (como o site facebook) passaram a ter na vida das pessoas.

Fica evidente que essa mudança de uma sociedade da posse para uma sociedade da aparência altera os vínculos entre os sujeitos, pois as características estimadas e cultivadas passam a ser a fama, a visibilidade e o exibicionismo. Nesse sentido, a inveja passa a ser o suporte subjetivo dos valores e condutas valorizadas socialmente, tal como a competição. A inveja (afeto) e a competição (conduta) constituem-se como agressões entre pares e representam uma díade de perversão dos relacionamentos contemporâneos, pois ambas atualmente perderam o seu sentido deletério inerente. Ser uma pessoa competitiva e/ou invejada tornou-se categoria positiva e socialmente glorificada (CANIATO; RODRIGUES, 2012).

O papel outrora desempenhado pelo mito e pela religião é assumido pela indústria cultural. Essa acaba por propagar um contexto de esvaziamento da palavra, uma vez que a linguagem perde sua importância diante do número e da imagem visual, e assim a capacidade de autorreflexão do sujeito é debilitada.

As epopeias gregas e as religiões submetiam o sujeito a sistemas de valores que o enlaçavam em uma tradição cultural 
| 264 |

Olho-gordo e fura-olhos na Sociedade do Espetáculo...

de respeito à tradição. Era preciso aceitar a história familiar e somente a partir dela constituir a própria narrativa de vida. Com a consolidação da indústria cultural torna-se um imperativo negar essa história aos pais e avós, relegando-os à posição de ultrapassados. Nesse movimento o sujeito se despe da própria história (ou possibilidade de construção dessas), e assim fica engessada a possibilidade de enfrentamento dessa tradição, que viria com a compreensão de que ela pode ser superada.

O vício e o pecado perderam a força como reguladores sociais, dando lugar à mercadoria, que afirma que tudo é permitido, desde que se consuma. Ela vem atrelada a um discurso que afirma ao sujeito que ele deve gozar "sem medo", "sem culpa"; no entanto, quando ele não consegue alcançar tal objetivo (e nunca consegue, pois a satisfação absoluta seria a morte do desejo), é jogado em um círculo de autopunição. Desnudado da própria história, esse sujeito permanece no vazio, e as promessas de preenchimento dele (pela mercadoria) o colocam na inveja.

$\mathrm{Na}$ atual fase do capitalismo expresso no espetáculo é preciso cometer todos os sete pecados capitais, anteriormente condenados. A soberba é autoafirmação e falsidade para viver dentro da selva do mundo do trabalho, que afirma que o "importante é vencer, a qualquer custo". É preciso avareza para acumular riqueza, ou seja, ter cobiça para conquistar toda espécie de bens. A ira é o ataque mais cabível, numa sociedade em que o ódio não é mais racional e ela, como aponta Tomás de Aquino, está sempre em inconformidade com a culpa. A acídia (divagação da mente) como a preguiça do pensar é a norma, um ataque à possibilidade do pensar. A luxúria (estímulo ao gozo) representa o imperativo de exacerbação da sexualidade, e impõe aos sujeitos uma falsa sexualidade que banaliza os vínculos entre os sujeitos. A inveja, que dentro da mitologia e da própria religião cristã é descrita como um sentimento destrutivo atrelado à rivalidade e à autodestruição, é agora difundida pela indústria cultural como categoria de estima. O valor social de uma pessoa, dentro de uma sociedade do espetáculo, é medido pela quantidade de pessoas que a invejam. A inveja acaba sendo sinônimo de admiração. 
As mercadorias oferecidas pela indústria cultural são tratadas como amuletos e talismãs, mas agora não mais protegem contra os invejosos, mas buscam atraí-los. Todos querem ser famosos, vistos e exaltados. É contemporânea a célebre frase "sua inveja faz a minha fama". O sujeito busca estimular no outro o sentimento de inferioridade - que, como apontou Freud (1925/1997), é uma característica daquele que sente inveja. Com isso ele repete entre os iguais a violência que sofreu ao sentir-se humilhado socialmente.

O sentimento de inveja possui registros antigos de sua existência. Desta forma, desde muito tempo a humanidade cria formas para lidar com o ataque advindo do invejoso. Os amuletos, mesmo de forma alienante, cumprem a função de fazer com que o sujeito fique alerta e não exposto ao "mau-olhado" dos outros. A arruda colocada em algum canto da casa materializava também a preocupação que o sujeito possuía de que algo atrapalhasse seu lar e sua família. Atualmente a indústria cultural busca quebrar qualquer barreira protetora, uma vez que nada deve impedir que o sujeito "realize seus desejos", compre tudo que queira e goze de sua pretensa onipotência.

\section{O mau-olhado na contemporaneidade}

O ser humano necessita do amparo físico e afetivo de outro ser humano para se desenvolver (FREUD, 1930/2011). Ele é um ser da relação, o que significa que ele não recebe a própria história e a própria subjetividade, mas as constrói em uma relação social. Como já apontamos, a inveja é um ataque ao vínculo de amparo com esse outro. Ela impossibilita o acolhimento. Nela, as diferenças individuais não são suportadas, o que traz consequências destrutivas à própria subjetividade do invejoso.

Para estimular à compra de mercadorias a indústria cultural construiu ideologias que difundem um estímulo ao "espírito independente" e a capacidade do sujeito de "prover suas próprias necessidades". Ao negar a importância do outro, o "si mesmo" 
acaba ficando em destruição. Paradoxalmente, o sujeito que nega sua dependência do outro se torna submisso aos ditames externos, pois se afasta de suas próprias escolhas, de seus limites, de sua singularidade e de seu desejo.

A indústria cultural passou a formar subjetividades cuja característica principal é a incredulidade nas próprias capacidades, pois é preciso estar "vazio" para ser livre e consumir incessantemente tudo que é oferecido. Com isso o sujeito se percebe a si mesmo como insuficiente.

Lasch (1987) analisa que esse contexto social desenvolve um novo tipo de autoconsciência, em que as mercadorias passaram a ditar não apenas o mundo externo, mas, fundamentalmente, o mundo interno dos sujeitos. O homem tornou-se uma coisa, e as coisas, projeções do eu. O mundo do consumo não é um mundo de coisas, mas de fantasias. Afirma o autor:

\begin{abstract}
A cultura organizada em torno do consumo de massa estimula o narcisismo - que podemos definir, para o momento, como a disposição de ver o mundo como um espelho, mais particularmente, como uma projeção dos próprios medos e desejos - não porque torna as pessoas grandiosas e agressivas, mas porque as torna frágeis e dependentes. Corrói a sua confiança na capacidade de entender e formar o mundo e de prover suas próprias necessidades. (LASCH, 1987, p. 24-25)
\end{abstract}

$\mathrm{O}$ autor ainda analisa que o estímulo à dependência do consumismo e do "amparo da tecnologia" (e acrescentamos do espetáculo) faz o sujeito reviver sentimentos infantis de desproteção. Esse contexto recria no mundo do consumo padrões orais enraizados numa fase arcaica do desenvolvimento, em que a dependência da mãe era completa; ou seja, "o consumidor percebe o mundo circundante como uma espécie de extensão do seio, altamente gratificador ou frustrante; reluta em conceber o mundo a não ser em conexão com suas fantasias" (LASCH, 1987, p. 25)

Diante da idealização da indústria cultural, o sujeito não consegue atacar suas ideologias, muito menos a base econômico- 
material que lhe dá sustentação. Apenas lhe é permitido atacar os iguais. Assim, o sujeito entra no círculo destrutivo da competição capitalista, em que todos são potenciais inimigos. A inveja sustenta esse processo, mantendo o sujeito regredido e impedido de desenvolver os elementos egoicos que fariam frente a essa violência.

Destarte, o sujeito submisso aos ditames da indústria cultural cultiva em si a inveja. Mediante a projeção de sua perfeição narcísica sobre as mercadorias ele tem a sensação de um retorno à sua onipotência primária. Esse mecanismo revela-se como uma alternativa de preservação de sua integridade e de enfrentamento dos seus sentimentos de impotência ante a impossibilidade de relacionar-se com o outro, pois nesse contexto só a mercadoria tem voz e vez.

O processo de individuação (tornar-se singular) pressupõe um afastamento da fusão originário da posição narcísica primitiva (FREUD, 1914/2004); no entanto, a própria "cultura" parece estar minando a possibilidade de o sujeito sair dessa posição, uma vez que não oferece ideais amparadores capazes de dar segurança e retorno ao investimento afetivo.

A inveja existe ao longo da história, mas na contemporaneidade ela toma formas específicas. O sentimento de roubo que o invejoso sente (causado idealização) hoje possui base real, pois a cada dia o sujeito é expropriado de seu trabalho, de seu lazer, de sua capacidade de pensar, de sua autonomia.

A identificação com os modelos dos meios de comunicação de massa se processa em um simbólico enganoso, visto que eles ocorrem com personagens fictícios, fato que aumenta ainda mais a manipulação das fantasias inconscientes no sujeito. A fantasia de plenitude, de independência total do objeto de amor é estimulada e prometida diariamente por meio das mercadorias.

As identificações passam a ser feitas não com o próximo - que, desqualificado, tornou-se desprezível e/ou até perigoso - mas com objetos distantes, abstratos, que não dão retorno afetivo à idealização que deles fazem os sujeitos. Cada qual está efetivamente só, regredido e enfraquecido, e apenas a dimensão 
| 268 |

Olho-gordo e fura-olhos na Sociedade do Espetáculo...

destrutiva de seu narcisismo, expressa na inveja, compele-o à ilusão de ser maravilhoso como o seu modelo.

\section{Considerações finais}

Em sua etimologia a palavra inveja já apresenta o verbo olhar (do latim invidia: olhar de soslaio, olhar atravessado). Essa marca também se faz presente na adjetivação do invejoso no senso comum: aquele que tem "olho gordo", que vai "furar olhos", que tem o olhar de "secar pimenta" ou ainda que lança um "mau-olhado".

É um costume universal e uma forma de superstição fechar os olhos dos mortos. Zuenir Ventura (1998) afirma que essa tradição tem suas raízes no costume de antigos povos que acreditavam que os mortos pudessem lançar olhares invejosos contra os vivos. Para Elias Canetti, escritor búlgaro, os mortos "partem cheios de inveja daqueles que deixaram para trás" (CANETTI apud VENTURA, 1998, p. 31). O jornalista também escreve que o filósofo Francis Bacon chamava a inveja de "ejaculação do olho".

No clássico da literatura "A Divina Comédia", de Dante Alighieri (2010), os invejosos habitam o segundo círculo do Purgatório, Canto XIII, e são descritos como aqueles que têm "os olhos cosidos com fio de arame" (ALIGHIERI, 2010, p. 198)

$\mathrm{Na}$ cultura popular, os patuás (amuletos) mais próprios para se "proteger" contra a inveja são os que possuem formato de olhos, como o Patuá de olho-de-lobo, o olhinho-africano e o olho-deturco (nazar boncuk). São muito freqüentes amuletos contra "mauolhado" que imitam olhos humanos ou de animais, como o olho de boi, de pombo e de cabra. Desta maneira, na inveja, sem dúvida, existe uma relação importante com a imagem visual.

O olhar é uma das formas mais arcaicas de interação com o mundo. Ele é anterior ao desenvolvimento da linguagem. Freud (1915/2004) define a existência de uma pulsão do olhar: a pulsão escópica - que se liga ao incosnciente, ou seja, opera segundo 
o princípio do prazer, cujo propósitoé a busca de alívio imediato, por meio do abaixamento das tensões. Com a aquisição da linguagem, o sujeito passa a ser guiado mais pelo princípio de realidade, cuja satisfação e alívio das tensões levam em consideração aspectos do meio no qual o sujeito está inserido, e, assim, a gratificação passa por uma avaliação das condições da realidade e pode ser adiada (FREUD, 1920). Nesses termos, a inveja dificilmente é verbalizada e avaliada segundo o princípio da realidade. Ela é negada justamente porque se liga a impulsos arcaicos e destrutivos no sujeito.

O ódio descrito no olhar do invejoso deixa suas marcas na cultura - por exemplo, no costume folclórico de se "proteger" do ataque invejoso devolvendo a ele o olhar (materializado nos patuás e amuletos, que em geral possuem o formato de olho). Assim, pelo olhar, o outro sente inveja, e como um espelho, devolve-se para o invejoso a agressividade lançada, como forma de defesa.

Podemos conjeturar que na sociedade do espetáculo-em que a imagem visual é mais valorizada e estimulada que a linguagem verbal - as capacidades egoicas conscientes, como a reflexão e a crítica, ficam lesadas. Assim, pelo olhar, o sujeito, na sociedade do espetáculo, atesta sua falência enquanto alguém que pensa e age sobre sua realidade, que tem um papel conscientemente ativo em relação à cultura.

Lispector (1998), por meio de um dos seus personagens, revela o caminho humano para a autonomia, que, no caso da inveja (e seu corolário social: a competição), traz um reconhecimento das diferenças e das próprias limitações - o que vai à contramão da onipotência atualmente estimulada. A autora, ao escrever sobre como sair do círculo da inveja, afirma: "[...] é necessário uma agonia de seu nascimento. Até então eu nunca vira coragem. A coragem de ser o outro que se é, a de nascer do próprio parto, e de largar no chão o corpo antigo" (LISPECTOR, 1998, p. 75). 
Olho-gordo e fura-olhos na Sociedade do Espetáculo...

\section{Bibliografia}

ADORNO, T., W. A indústria Cultural. In. G. Cohn (org). Theodor Adorno: Sociologia. São Paulo: Ática, 1986.

ALIGHIRI, D. A Divina Comédia. São Paulo: Abril, 2010.

BULFINCH, T. O livro de Ouro da Mitologia: histórias de Deuses e Heróis. Rio de Janeiro: Ediouro, 2001.

CANIATO, A, M, P; RODRIGUES, S, M. "A construção psicossocial da competição: o engano na cumplicidade de uma falsa vida". Psicologia \& Sociedade, Porto Alegre, v. 24, n. 1, 23-35, 2012.

CHUSTER, A; TRACHTENBER, R. As sete invejas capitais: uma leitura contemporânea sobre a complexidade do mau. Porto Alegre: Artmed, 2009.

CUNHA, A., G., da. Dicionário Etimológico. Rio de Janeiro: Nova Fronteira, 1991.

DEBORD, G. A sociedade do Espetáculo. Rio de Janeiro: Contraponto, 1997.

FREUD, S. (1905) Três ensaios sobre a teoria da sexualidade. In: FREUD, S. Obras Completas. Rio de Janeiro: Imago, 1997, vol. VII.

(1914) À guisa de introdução ao narcisismo. In: FREUD, S. Escritos sobre psicologia do inconsciente. Obras psicológicas de Sigmund Freud. Rio de Janeiro: Imago, 2004, vol. I.

. (1915) Pulsão e destinos das pulsões. In: FREUD, S. Escritos sobre psicologia do inconsciente. Obras psicológicas de Sigmund Freud. Rio de Janeiro: Imago, 2004, vol. I.

. (1920). Além do princípio do prazer. In: FREUD, S. Obras Completas. Rio de Janeiro: Imago, 1997, vol. XVIII.

(1930) El Malestar en la Cultura. In: FREUD, S. Obras Completas. Madrid: Biblioteca Nueva, 1981. 
. (1937). Análise Terminável e interminável. In: FREUD, S. Obras Completas. Rio de Janeiro: Imago, 1997, vol. XXIII.

HORKHEIMER, M; ADORNO, T, W. O conceito de Esclarecimento. In: . Dialética do Esclarecimento - fragmentos filosóficos.

Rio de Janeiro: Jorge Zahar, 1985a. p. 19-52.

Indústria Cultural: O Esclarecimento como Mistificação das Massas. In: . Dialética do Esclarecimento - Fragmentos filosóficos. Rio de Janeiro. Rio de Janeiro: Jorge Zahar, 1985b. p. 113-156

KLEIN, M. (1957). Inveja e Gratidão. Rio de Janeiro: Imago, 1991.

KLEIN, Melanie; RIVIERE, Joan. Amor ódio e Reparação. Rio de Janeiro: Imago, 1975.

LASCH, C. O mínimo eu: sobrevizência psíquica em tempos difíceis. São Paulo: Brasiliense, 1997.

LISPECTOR, C. A legião Estrangeira. In C. Lispector. Felicidade Clandestina: contos. Rio de Janeiro: Rocco, 1998.

MARX, K. (1867) O Capital. Rio de Janeiro: Civilização Brasileira, 1968.

MEZAN, R. A Inveja. In: . Os sentidos da Paixão. São Paulo: Companhia das Letras, 1997.

OVÍDIO. Metamorfoses. São Paulo: Madras, 2003.

TOMÁS DE AQUINO. Suma Teológica (II- II). São Paulo: edições Loyola, 2005, vol. II-II.

VENTURA, Z. Inveja o Mal secreto. Rio de Janeiro: Objetiva, 1998. 